\title{
Reclaimed artificial coastal territories for the development of urban areas
}

\author{
Mikhail Shilin ${ }^{1,}$, Alexandra Ershova ${ }^{1}$, Yuri Matveev ${ }^{1}$, Nikolay Popov ${ }^{1}$, Olga Mandryka ${ }^{1}$, \\ and Alexander Chusov ${ }^{2}$ \\ ${ }^{1}$ Russian State Hydrometeorological university, Malookhtinskiy Prospekt, 98, Saint-Petersburg, \\ 195196, Russia \\ ${ }^{2}$ Peter the Great Saint-Petersburg Polytechnic University, Polytechnicheskaya, 29, St. Petersburg, \\ 195251, Russia
}

\begin{abstract}
The article discusses the possibility and perspectives of using the reclaimed artificial areas in the coastal zone of marine estuaries for the sustainable development of urban infrastructure and creation of modern architectural ensembles with the background of green economy using the example of Lakhta-Center on the northern coast of the Neva Bay (St. Petersburg, Russia). The geo-ecological stability of underwater and coastal landscapes of the coastal zone of the Neva Bay is analyzed using side scan sonar. The environmental sensitivity of coastal ecosystems is estimated. The received data can be used on practice for planning the construction work and for the development of the infrastructure of urbanized coastal zone of the Neva Bay. The general geo-ecological situation in the observed area is rather stable. The coastal zone has good perspectives for the development of a sustainable urban infrastructure against the backdrop of the green economy. The special attention should be paid to migration of birds and fish, who are using the North Lakhta coast as a temporary refugium during Spring and Autumn migrations. An effective solution from both environmental and economic points of view could be the organization of the Nature Conservation Reserve, which is spatially associated with the Lakhta Center zone. Such type of the complex using of the coastal zone could be a good example of the spatial planning in the environmentally sensitive area.
\end{abstract}

\section{Introduction}

Within green economy, the management of environmental risks is an important aspect of large projects, for example, in the field of sustainable development of cities [1-5] and municipalities [6], or in environmental management [7], including coastal zones [8]. For such risk management, we propose to use geo-information support [9-11] based on the principles of geo-information management for complex geographically distributed systems [12-17]. If the projects are implemented in the Arctic and subarctic regions [18], the composition of natural risks must take into account climate change, due, inter alia, the

\footnotetext{
* Corresponding author: mik.shilin@mail.ru
} 
influence of black carbon [19] the inflow into the Arctic ocean of Pacific and Atlantic waters [20, 21], as well as the flow of Arctic rivers [22].

The natural risk management while large projects incuding marine pipe line [23-25] and the construction of civil buildings complex ensembles on the artificially reclaimed coastal areas, is important aspect for the development of modern cities located in the coastal zones. In St. Petersburg area on reclaimed territories, they created the new port complex «Marine Facade of St. Petersburg», the Park devoted to 300-anniversary of the city, the avant-port «Bronka», the «Gazprom-Arena» stadium etc. On March 10, 2011, the PJSC «Gazprom» acquired a plot of land on the north coast of the Neva Bay in the outskirts of St. Petersburg with a total area of $140,000 \mathrm{~m}^{2}$ for construction of an office building «Lakhta Center». The entire site is located within a coastal area which was artificially formed in 1960-1970s, when a vast sand pile was organized here, and which until 2011 occupied the main area of the site. Thus, construction of «Lakhta Center» does not involve the destruction of any historical landscapes or ecologically valuable coastal biological communities. The Tower of «Lakhta Center» will consist of 86 floors above the ground and 3 underground levels. The absolute elevation of the top of the spire is $500 \mathrm{~m}$. The Tower should become the tallest building in Russia and in Europe. The location of the building and its height is expected to make the Tower one of the new symbols of Saint-Petersburg and to promote the popularity of the new facility among the tourists. Construction of the «iconic building» Lakhta Center and the associated infrastructure on the artificially formed territory should represent a new idea in using coastal zones in urban construction.

For sustainable organizing of the urban infrastructure, it is necessary to analyze the general stability of coastal ecosystems, and their sensitivity to different kinds of anthropogenic pressure. The results of such analysis can be used as a basis for spatial planning for sustainable development the north coast of the Neva Bay, with green economy as a background.

\section{Methods and data}

In research, we used risk management approach, theory of decision making under uncertainties. As part of geographic information management, we structured geo-space to allocate the interconnected components of the solution space $[12,15]$. During the long-time investigation carried out in $2004-2018$, we used: scanning underwater landscapes with side scan sonar; monitoring of coastal ecosystems on the basis of satellite information; analysis of risk factors in the coastal zone connected with anthropogenic activities; observation on the behavior of migrating birds and fish in the area of the north coast of the Neva Bay. Scenarios of the coastal zone development were elaborated in order to provide the long-term geo-system stability.

\section{Results}

The underwater landscape of the Neva Bay bottom near the Lakhta Center is initially even and smooth due to the silt carried by the Neva river waters. The Neva River deposits have been smoothing the roughness of underwater landscapes here creating favorable conditions for the development and succession of the «soft benthos» communities. Coastal «shallow water banks» served as places of feeding for bottom-feeding fish, as well as for stops and feeding of birds during spring and autumn migrations from Europe to Russian tundra (for nesting) and backwards (fig. 1). In case of development of the thickets of highest aquatic vegetation in shallow waters, they served also as fish spawning areas and «fish nursery» as well as nesting sites for waterbirds during the summer. 


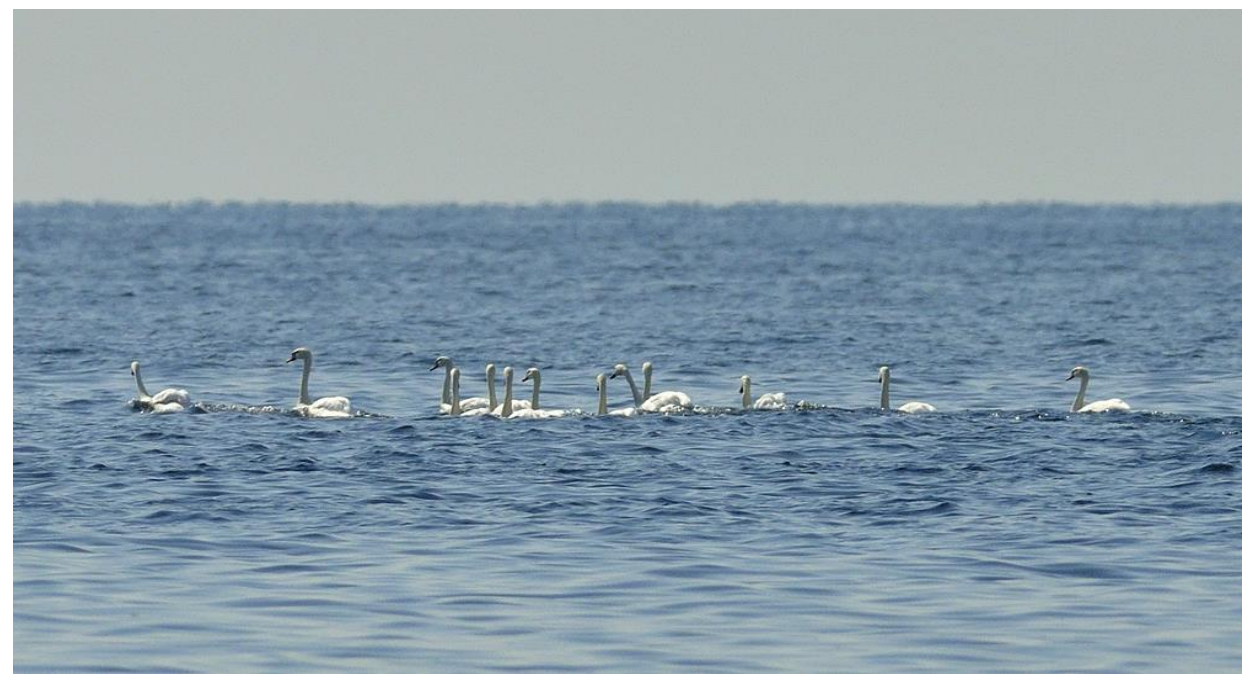

Fig. 1. Migrating swans (Cygnus olor) on the stop for feeding and relaxation (Spring 2018).

However, during the last decades of XX century this area became a site of marine sand quarrying with two sites (polygons) for the dredging material underwater placement «North Lakhta» and «South Lakhta». During 2005 - 2008, they located 21.4 million $\mathrm{m}^{3}$ of dredged material in these deposit sites, removed during the reconstruction of waterways near the eastern coast of the Neva Bay and realization of the first leg of the project «Marine Facade of St. Petersburg» (fig. 2).

The intensive dredging work resulted in an entire anthropogenic transformation of bottom relief and sediments. Now there is a distinctive technogenic relief represented by a chaotic distribution of «peaks» (unfinished sand deposits and dumped dredging material) and pits with a relative depth up to 4-5 $\mathrm{m}$ (with an absolute depth up to 10-12 $\mathrm{m}$ ). Underwater landscapes here are at a stage of continuous reorganization. In general, the dumping areas «North and South Lakhta» (fig. 3) can be characterized as low-productive and low-feeding for benthos-feeding fish.

Coastal feeding shallow banks have practically lost their ecological role as feeding areas for fish and waterbirds (fig. 4). Migrating birds have a transit flight fly over the area of Lakhta Center, with no stop for feeding.

Analysis of the satellite images from 2004 and 2011 did show that the coastal line in the area of the «Lakhta Center» area is rather stable and can be used for the long-term infrastructure development (fig. 5). During the Winter time, the additional factor of geological risk in the cooastal zone is represented by the moving ice cover (fig. 6). The coast in the observed area is effected by mechanic ice disturbance during the period more than 3 mothts. 

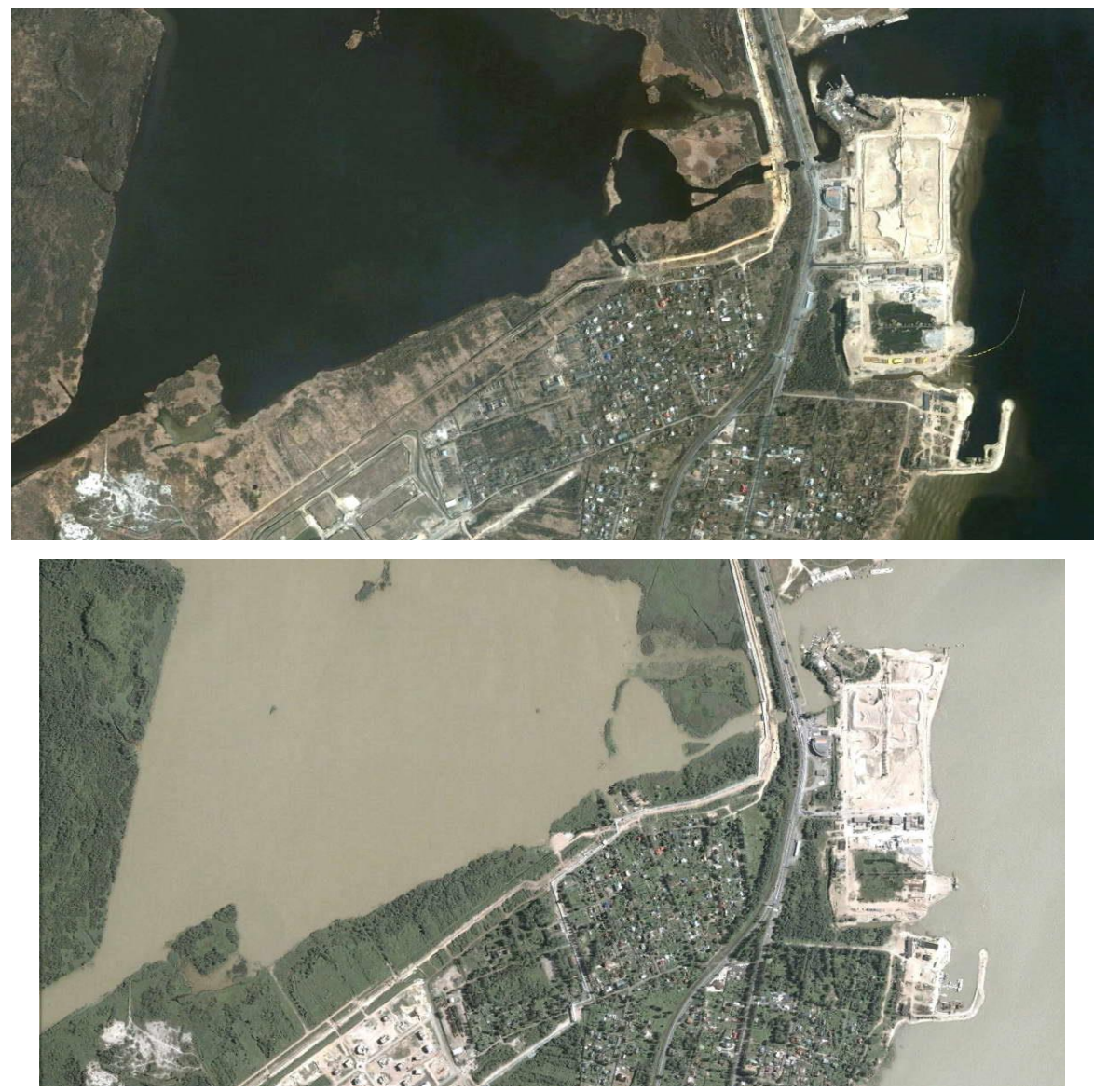

Fig. 2. Concentration of suspended material in the North Lakhta area before the construction of «Marine Facade of St. Petersburg» (above, 2004) and during the dredging work (below, 2011).

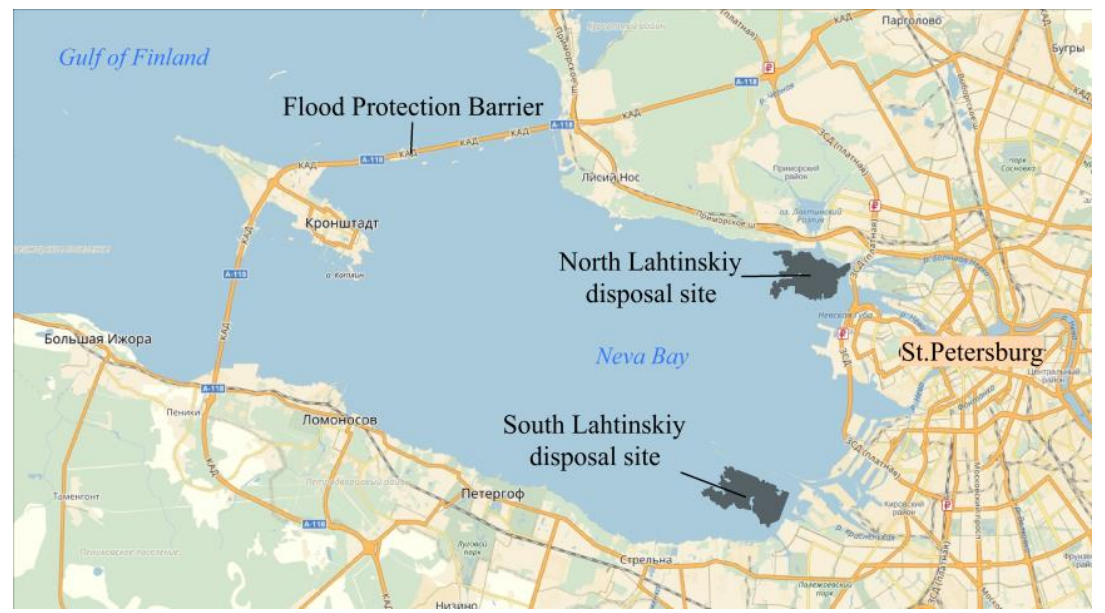

Fig. 3. The dumping areas «North and South Lakhta». 


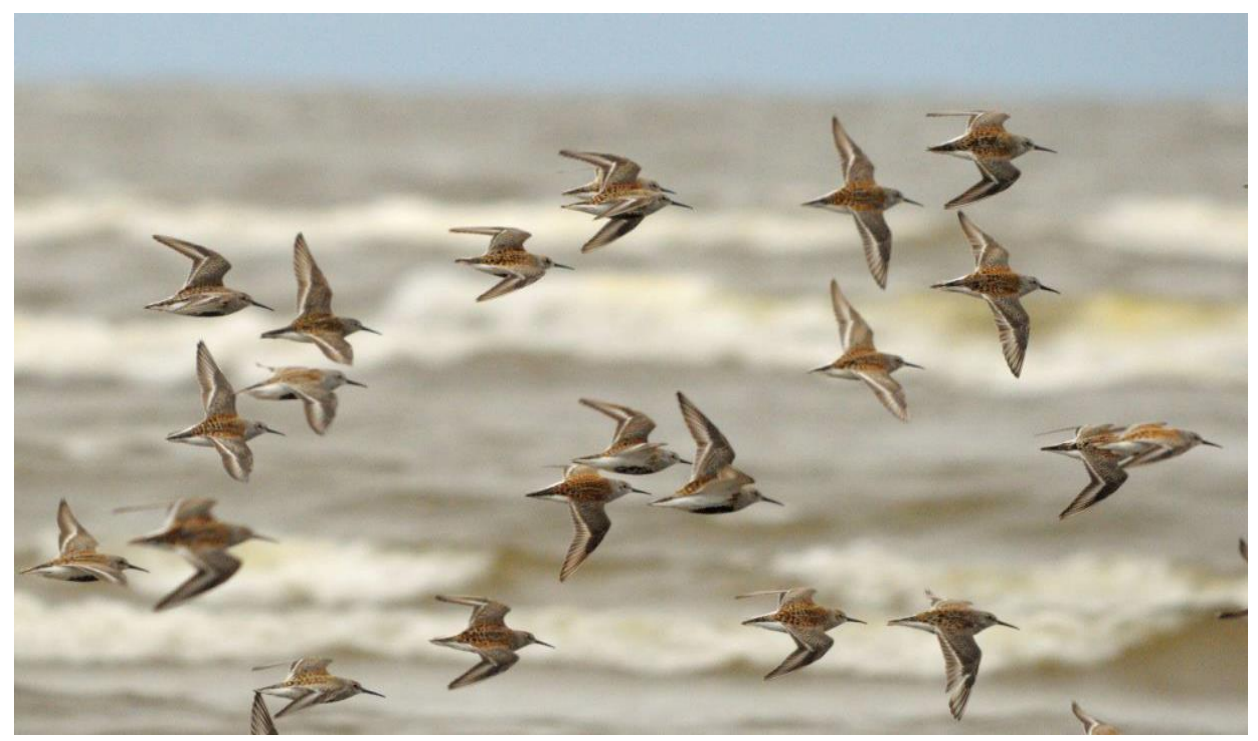

Fig. 4. Sindpipers Calidris alpine flying over the Lakhta coastal zone on the way to Russian tundra (2012).

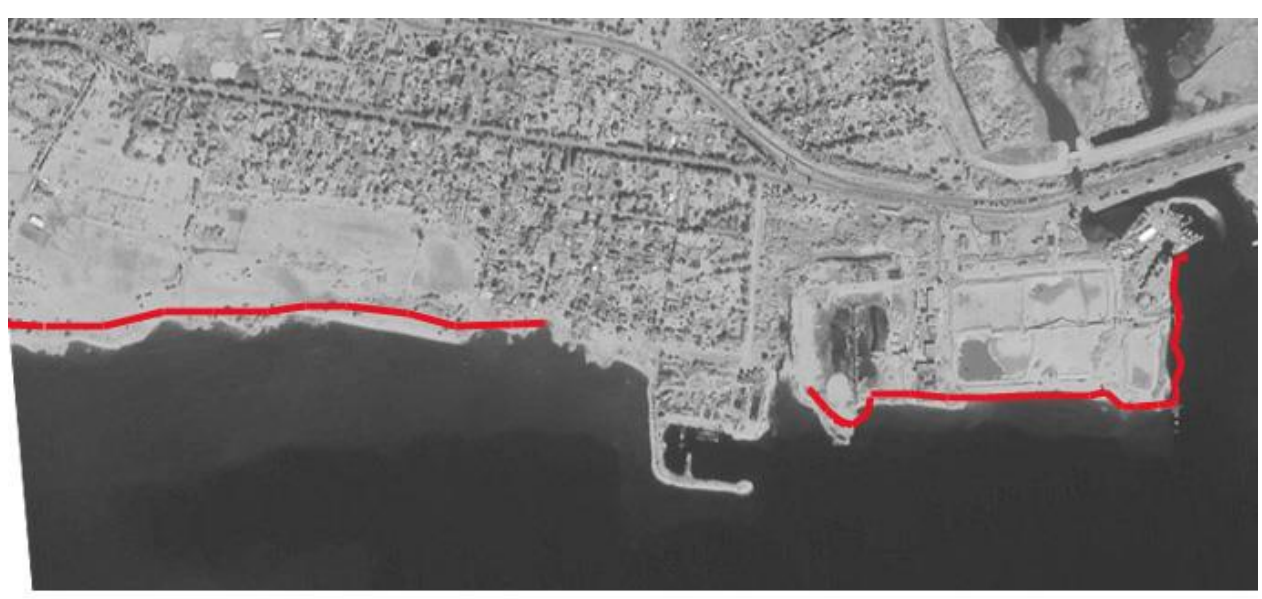

\section{Landsat 5, 2011} \& 2004

Fig. 5. The coastal line in the «Lakhta Center» area was rather stable during 2004 and 2011. 


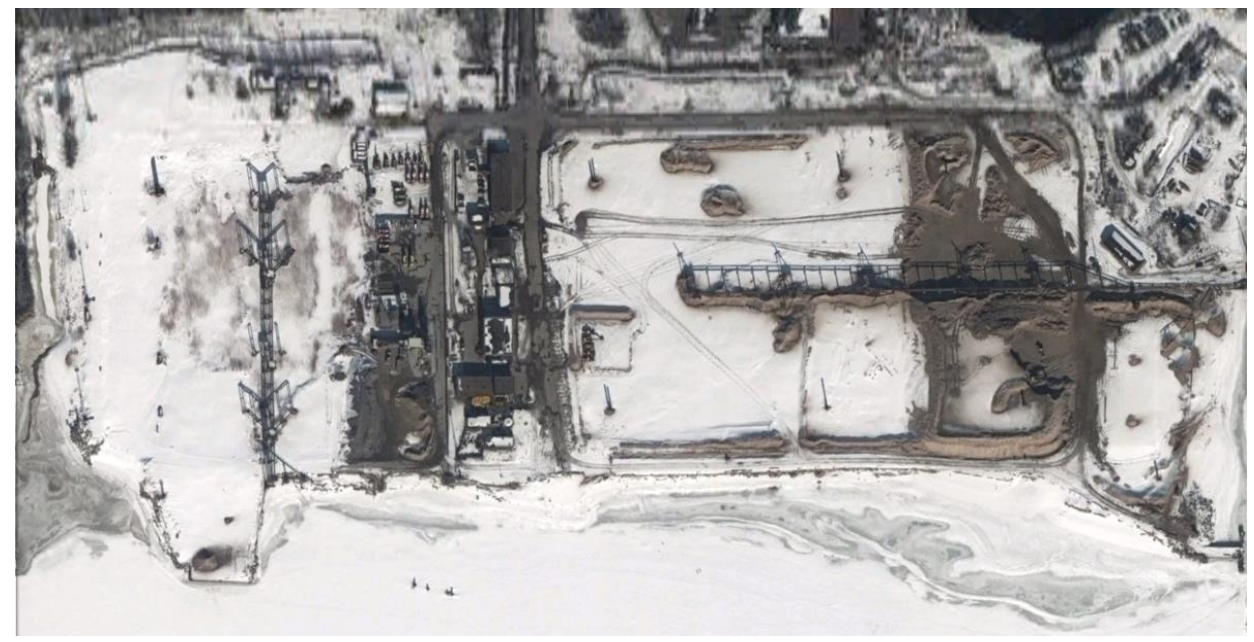

Fig. 6. The whole coastal zone of the «Lakhta Center» area is covered by ice (satellite image from 2012).

Note, results of research allowed to elaborated scenarios of the coastal zone development in order to provide the long-term geo-system stability.

\section{Discussion}

The restoration of natural smoothed and leveled underwater landscapes of the North Lakhta area is possible by means of filling of the existing ditches with the material removed during construction, reconstruction and repair of maritime routes and water areas. The expected area of the filled ditches can make 531.5 ha. The depth of a dump site can be minus $4 \mathrm{~m}$, and when using a hydrodynamic technology of the dredged material placement - up to minus $3 \mathrm{~m}$. For the transportation of dredged material, the hoppers with a hold volume of $500 \mathrm{~m}^{3}$ will be used. General duration of works can make 5 years; the volume of ditches with minus $4 \mathrm{~m}$ mark - 12163.500 thousand $\mathrm{m}^{3}$.

In order to restrict the negative impact on biota and provide conditions for spawning and feeding of smelts and other commercial fish, the following measures must be foreseen by the project: (1) recultivation of mined-out underwater mineral deposits; (2) development of artificial spawning areas in coastal waters around the North Lakhta shallow water bank; (3) formation of artificial multifunctional shallow water banks and islands attracting benthosfeeding fish and waterbirds. This approach can become a positive example of underwater landscape management in the Neva Bay.

\section{Conclusion}

The general geo-ecological situation in the observed area is rather stable. The coastal zone has good perspectives for the development a sustainable urban infrastructure, with the green economy as a background. The special attention should be paid to migration of birds and fish, who are using the North Lakhta coast as a temporary refugium during Spring and Autumn migrations. An effective solution from both environmental and economic points of view could be the organization of the Nature Conservation Reserve, which is spatially associated with the Lakhta Center zone. Such type of the complex using of the coastal zone could be a good example of the spatial planning in the environmentally sensitive area. 


\section{References}

1. I. Zaychenko, A. Borremans, S. Gutman, E3S Web of Conferences 33, 03010 (2018)

2. A. Izotov, O. Rostova, A. Dubgorn, E3S Web of Conferences 33, 03008 (2018)

3. V. Vilken, O. Kalinina, A. Dubgorn, E3S Web of Conferences 33, 03012 (2018)

4. M. Beekmann, Atmos. Chem. Phys. 15, 9577-9591 (2015)

5. C. Samara, D. Voutsa, A. Kouras, K. Eleftheriadis, T. Maggos, D. Saraga, M. Petrakakis, Environmental Science and Pollution Research 21(3) (2014)

6. G. Gogoberidze, L. Karlin, V. Abramov, J. Lednova, 2014 IEEE/OES Baltic International Symposium (2014) DOI: 10.1109/BALTIC.2014.6887840

7. V.A. Zhigulsky, M.B. Shilin, V.M. Abramov, A.A. Ershova, International Multidisciplinary Scientific GeoConference Surveying Geology and Mining Ecology Management 18(5.1), 423-430 (2018)

8. G. Gogoberidze, N. Popov, V. Abramov, A. Ershova, J. Lednova, International Multidisciplinary Scientific GeoConference Surveying Geology and Mining Ecology Management 17(52), 951-958 (2017)

9. J.A. Garcia, V.M. Abramov, E.P. Istomin, International Multidisciplinary Scientific GeoConference Surveying Geology and Mining Ecology Management 18 (2.2), 261268 (2018)

10. G. Gogoberidze, E. Rumyantseva, V. Abramov, N. Rodin, G. Vladimirova, International Multidisciplinary Scientific GeoConference Surveying Geology and Mining Ecology Management 17(52), 921-926 (2017)

11. A.A. Fokicheva, E.P. Istomin, V.M. Abramov, V.G. Burlov, A.G. Sokolov, International Multidisciplinary Scientific GeoConference Surveying Geology and Mining Ecology Management 18 (2.2), 377-384 (2018).

12. A.A. Fokicheva, E.P. Istomin, A.G. Sokolov, V.M. Abramov, G.G. Gogoberidze, International Multidisciplinary Scientific GeoConference Surveying Geology and Mining Ecology Management 1(2), 729-736 (2015)

13. E.P. Istomin, V.M. Abramov, V.G. Burlov, A.G. Sokolov, N.N. Popov, International Multidisciplinary Scientific GeoConference Surveying Geology and Mining Ecology Management 17(21), 859-866 (2017)

14. V.G. Burlov, A.G. Sokolov, V.M. Abramov, E.P. Istomin, A.A. Fokicheva, International Multidisciplinary Scientific GeoConference Surveying Geology and Mining Ecology Management 18(2.2), 483-490 (2018)

15. E.P. Istomin, A.G. Sokolov, V.M. Abramov, G.G. Gogoberidze, N.N. Popov, International Multidisciplinary Scientific GeoConference Surveying Geology and Mining Ecology Management 1(2), 607-614 (2015)

16. L.S. Slesareva, E.P. Istomin, V.M. Abramov, A.G. Sokolov, V.G. Burlov, International Multidisciplinary Scientific GeoConference Surveying Geology and Mining Ecology Management 17(21), 951-959 (2017)

17. A.G. Sokolov, E.P. Istomin, V.M Abramov, V.G. Burlov, A.A. Fokicheva, International Multidisciplinary Scientific GeoConference Surveying Geology and Mining Ecology Management 17(21), 1005-1012 (2017)

18. J. Lednova, G. Gogoberidze, V.M. Abramov, L.N. Karlin, S. Berboushi, International Multidisciplinary Scientific GeoConference Surveying Geology and Mining Ecology Management 1(5), 161-168 (2014) 
19. V.M. Abramov, G.G. Gogoberidze, N.N. Popov, A.V. Isaev, S.V. Berboushi, International Multidisciplinary Scientific GeoConference Surveying Geology and Mining Ecology Management 1(4), 953-960 (2015)

20. L.V. Alexandrova, N.N. Popov, V.M. Abramov, G.G. Gogoberidze, L.N. Karlin, International Multidisciplinary Scientific GeoConference Surveying Geology and Mining Ecology Management 2(3), 701-708 (2015)

21. L.V. Alexandrova, A.V. Bournashov, V.M. Abramov, G.G. Gogoberidze, L.N. Karlin, International Multidisciplinary Scientific GeoConference Surveying Geology and Mining Ecology Management 2(3), 661-668 (2014)

22. G.G. Gogoberidze, V.A. Golosovskaya, V.M. Abramov, L.N. Karlin, International Multidisciplinary Scientific GeoConference Surveying Geology and Mining Ecology Management 1(3), 495-501 (2014)

23. J., Lednova, A., Chusov, M. Shilin, Proceedings of the 10th Global Congress on ICM: Lessons Learned to Address New Challenges, EMECS 2013 - MEDCOAST, 1023-1034 (2013)

24. J., Lednova, M., Shilin, A., Chusov, S. Kouzov, IEEE/OES Baltic International Symposium 2014, BALTIC 2014 (2014) DOI: 10.1109/BALTIC.2014.6887863

25. J. Lednova, A. Chusov, M. Shilin, Ocean: Past, Present and Future - 2012 IEEE/OES Baltic International Symposium, BALTIC 2012 (2012) DOI: 10.1109/BALTIC.2012.6249169 